\title{
Evaluation of Surface Water Characteristics for Sustainable Aquatic Life: A Case Study of Ukpiovwin River, Udu Local Government Area, Delta State, Nigeria
}

\author{
Nwokoro Chijioke, Onosemuode Christopher
}

\begin{abstract}
The study of the water characteristics of Ukpiovwin River was carried out with a view of determining the concentration of some metals for the sustainability of the aquatic ecosystem. Surface water samples were collected at a depth of 0-100 cm, with $1 \mathrm{~L}$ plastic containers that were pre-rinsed with trioxonitrate (v) acid for $24 \mathrm{~h}$ and rinsed with de-ionized water. The concentrations of the metals (As, Ba, Mn, Zn, Pb, Hg, Cd, $\mathrm{Cr}, \mathrm{Cu}, \mathrm{Fe}, \mathrm{Ni}$, and $\mathrm{V}$ ) were determined using a varian atomic absorption spectrophotometer (spectra AA-100). The study shows that apart from As, Ba, Ni and $V$ were below the FEPA limit. The range of concentration of metals that were above the FEPA limit are the in the order of $\mathrm{Cd}<\mathrm{Cu}<\mathrm{Ma}<\mathrm{Hg}<\mathrm{Pb}<\mathrm{Zn}<\mathrm{Cr}<<\mathrm{Fe}$. The presence of the metals above the FEPA limit in the aquatic ecosystem is of great threat aquatic plants and organisms.
\end{abstract}

Index Terms - Aquatic, Contamination, Ecosystem, Heavy Metals, Sustainability.

\section{INTRODUCTION}

The major source of fresh water is the river which carries along its course reasonable quantity or load of matter which are either in dissolved or particulate form. These may have originated from both natural and anthropogenic sources [1].

The aquatic ecosystem has been known to play major roles in food chain process either directly or indirectly in sustaining human existence [2], [3], [4].The activities of oil exploitation and exploration have greatly impacted the ecosystem [2], [5], [6], [7], [8].

Besides the activities of exploitation and exploration, the aquatic ecosystem also receives materials and substances arising from municipal, domestic and industrial wastes [9]. Runoffs from agricultural farms and other pollutant generating sources eventually are deposited in water introducing pollutants into the aquatic ecosystem [10]. Due to the incessant increase in population growth, which is accompanied with rapid urbanization and industrial activities, discharges of wastes into the aquatic environment is on the increase [11]. Aquatic flora and fauna are always in

Nwokoro Chijioke, Department of Environmental Technology and Management, Faculty of Management, Lincoln University College

Onosemuode Christopher, Department of Environmental Management and Toxicology, College of Science, Federal University of Petroleum Resources, Effurun, Delta State, Nigeria continuous contact with water, which implies that they are directly affected by any change in water quality.

Aquatic organisms are exposed to a significant amount of pollutants, especially to heavy metals derived from geogenic, industrial, agricultural, pharmaceutical, and domestic effluents that lead to biochemical disturbances [12], [13], [14], [15], [16], [17].

Over exploitation and exploration of the natural environment without recourse to laid down rules or principles results in the deposition of toxic substances in the ecosystem [18]; [19]. Contaminants which originated from agricultural waste, factory discharge channels and effluents sources are discharged into the environment, which enhances or increases the total contaminant burden of the receiving environment (whether aquatic or terrestrial). Furthermore, the degree and nature of the movement of contaminants is dependent on the characteristics of the source and the receiving environment [20]. Physiochemical properties of water such as $\mathrm{pH}$, conductivity, total organic carbon, total organic matter, etc. determines the level or the extent to which heavy metals can be retained in the media. These help in the movement and toxicological properties of the metals [21]. The aquatic ecosystem in the study area has witnessed a multiplicity of degradation resulting from activities of oil exploitation and exploration, waste from industrial, municipal and agricultural sources; consequent upon these, this study is aimed at evaluating the surface water characteristics for sustainability of aquatic ecosystem.

\section{MATERIALS AND METHODS}

Surface water samples were collected at a depth of $0-100 \mathrm{~cm}$, with $1 \mathrm{~L}$ plastic containers that were pre-rinsed with trioxonitrate (v) acid for $24 \mathrm{~h}$ and rinsed with de-ionized water. Water samples were collected from eleven locations along the length of the river and the samples were then placed in a box containing ice packs, transported to the Laboratory, and stored at a temperature of about $4{ }^{0} \mathrm{C}$ prior to analyses. The samples were analyzed quantitatively in the laboratory for the following physicochemical parameters such The concentrations of the metals (As, Ba, $\mathrm{Mn}, \mathrm{Zn}, \mathrm{Pb}, \mathrm{Hg}, \mathrm{Cd}, \mathrm{Cr}$, $\mathrm{Cu}, \mathrm{Fe}, \mathrm{Ni}$, and $\mathrm{V}$ ) were determined using a varian atomic 


\section{Evaluation of Surface Water Characteristics For Sustainable Aquatic Life: A Case Study of Ukpiovwin River, Udu Local Government Area, Delta State, Nigeria}

absorption spectrophotometer (spectra AA-100). All samples were run in triplicates and the relative standard deviation for the triplicate analysis was less than $10 \%$. Standard solutions of the metals were prepared from their $1000 \mathrm{ppm}$ stock solutions for calibration.

\section{RESULTS AND DISCUSSION}

\section{Physicochemical Characteristics of Surface Water}

The physicochemical characteristics of surface water samples are summarized in Table 1.

Table 1 show the concentration of the various mental sampled across the study area. The mean of the locations were used as basis of comparison with the FEPA adopted in this study. The element Arsenic (As) has mean value of $0.05 \mathrm{mg} / \mathrm{l}$ which is below the FEPA limit of $0.02 \mathrm{mg} / 1$ with its highest concentration in location $5(0.13 \mathrm{mg} / \mathrm{l})$. When available in excess it inhibits growth and retards photosynthesis in plants and also affects the reproduction system of aquatic organism. Barium (Ba) has a mean value of $0.07 \mathrm{mg} / \mathrm{L}$ which is also below the FEPA limit of $1.0 \mathrm{mg} / 1$. Its concentration in study area ranges from $0.07 \mathrm{mg} / \mathrm{L}$ to $0.13 \mathrm{mg} / \mathrm{L}$, it's a trace element playing important role in mineral and hormonal metabolism but when consumed or absorb in large quantity it become toxic to plants and may affect growth and disturbance in homeostasis.

Table1: Values and mean concentrations of heavy metals in the surface water in the study area.

\begin{tabular}{|c|c|c|c|c|c|c|c|c|c|c|c|c|c|c|}
\hline \multirow[b]{2}{*}{ Parameters } & \multicolumn{11}{|c|}{ Sample Locations } & \multirow[b]{2}{*}{ Mean } & \multirow[b]{2}{*}{ SD } & \multirow[b]{2}{*}{$\begin{array}{l}\text { FEPA } \\
\text { LIMIT } \\
\end{array}$} \\
\hline & L1 & L2 & $\mathbf{L 3}$ & L4 & L5 & L6 & L7 & L 8 & L9 & L10 & L11 & & & \\
\hline As $(\mathrm{mg} / \mathrm{L})$ & 0.04 & $<0.03$ & 0.02 & 0.04 & 0.13 & 0.03 & $<0.03$ & 0.02 & 0.1 & 0.03 & 0.04 & 0.05 & 0.03 & 0.2 \\
\hline $\mathrm{Ba}(\mathrm{mg} / \mathrm{L})$ & 0.07 & $<0.12$ & 0.02 & 0.11 & 0.1 & 0.13 & 0.05 & 0.1 & 0.06 & 0.04 & 0.03 & 0.07 & 0.03 & 1.0 \\
\hline $\mathrm{Cu}(\mathrm{mg} / \mathrm{L})$ & $<0.00$ & 0.14 & 0.12 & 0.1 & 0.12 & 0.17 & 0.1 & 0.18 & 0.18 & $<0.00$ & 0.09 & 0.13 & 0.03 & 0.1 \\
\hline $\mathrm{Mn}(\mathrm{mg} / \mathrm{L})$ & 0.24 & 0.42 & 0.1 & 0.23 & 0.22 & 0.23 & 0.19 & 0.28 & 0.13 & 0.35 & 0.28 & 0.24 & 0.08 & 0.05 \\
\hline $\mathrm{Fe}(\mathrm{mg} / \mathrm{L})$ & 15.07 & 22.32 & 7.97 & 17.21 & 15.46 & 9.67 & 9.99 & 8.74 & 15.88 & 16.29 & 17.6 & 14.20 & 4.29 & 1.0 \\
\hline $\mathrm{Cr}(\mathrm{mg} / \mathrm{L})$ & 5.23 & 16.29 & 10.54 & 1.7 & 7.44 & 19.38 & 9.66 & 18.5 & 7.89 & 7 & 8.77 & 10.21 & 5.33 & 0.05 \\
\hline $\mathrm{Cd}(\mathrm{mg} / \mathrm{L})$ & 0.05 & $<0.02$ & 0 & 0 & $<0.00$ & 0 & 0.06 & 0.02 & 0.07 & 0.07 & 0.03 & 0.03 & 0.02 & 0.01 \\
\hline $\mathrm{Zn}(\mathrm{mg} / \mathrm{L})$ & 1.78 & 4.73 & 3.59 & 8.63 & 6.58 & 9.77 & 7.89 & 4.77 & 2.47 & 6.8 & 7.11 & 5.82 & 2.44 & 5.0 \\
\hline $\mathrm{Ni}(\mathrm{mg} / \mathrm{L})$ & $<0.01$ & $<0.01$ & $<0.01$ & $<0.01$ & $<0.01$ & $<0.01$ & $<0.01$ & $<0.01$ & $<0.01$ & $<0.01$ & $<0.01$ & 0.01 & 0.01 & 0.05 \\
\hline $\mathrm{Pb}(\mathrm{mg} / \mathrm{L})$ & 0.61 & 0.46 & 0.27 & 0.88 & 0.59 & $<0.01$ & $<0.01$ & $<0.01$ & $\begin{array}{l}<0.00 \\
1\end{array}$ & 0.68 & 0.07 & 0.50 & 0.24 & 0.05 \\
\hline $\mathrm{Hg}(\mathrm{mg} / \mathrm{L})$ & 0 & 0.01 & 0 & 2.9 & 0 & 0 & 0 & 0 & 0 & 0.5 & 0 & 0.31 & 0.83 & 0.001 \\
\hline $\mathrm{V}(\mathrm{mg} / \mathrm{L})$ & 0 & $<0.01$ & $<0.00$ & $<0.01$ & $<0.01$ & $<0.01$ & $<0.01$ & $<0.01$ & $<0.01$ & $<0.01$ & $<0.01$ & - & ND & 0.01 \\
\hline
\end{tabular}

The mean value of Copper $(\mathrm{Cu})$ in the study is $0.13 \mathrm{mg} / \mathrm{L}$ which is greater than the FEPA limit of $0.1 \mathrm{mg} / \mathrm{L}$, with the highest concentration of $0.18 \mathrm{mg} / \mathrm{L}$ in locations 8 and 9 . With excess of copper in the study area, the plants may become toxic with time, the algae, fungi, molluscs and fish are bound to die. The osmo-regulation and ion regulation in the gill of fish in the aquatic ecosystem will also be impaired.

The mean value of Manganese $(\mathrm{Mn})$ is $0.24 \mathrm{mg} / \mathrm{L}$ which is higher than the FEPA limit of $0.05 \mathrm{mg} / \mathrm{L}$ with its highest concentration in location $10(0.35 \mathrm{mg} / \mathrm{L})$. The immune response in aquatic animals may be damaged due to excess manganese found in the study area. It also leads to genotoxicity that may cause oxidative stress in gills and intestinal inflammatory damages in fish.

The mean value of Iron (Fe) across the study area is $14.20 \mathrm{mg} / \mathrm{L}$ which far above the FEPA limit of $1.0 \mathrm{mg} / \mathrm{L}$ with its highest concentration in location $2(22.32 \mathrm{mg} / \mathrm{L})$. Excessive of $\mathrm{Fe}$ found in the study can damage the gills of fish and when iron builds in the internal organs of aquatic animals it kills them with time. It's presence in excess also distorts the growth of plants in the aquatic ecosystem.

The mean value of Chromium $(\mathrm{Cr})$ is $10.21 \mathrm{mg} / \mathrm{L}$, this is far above the FEPA limit of $0.05 \mathrm{mg} / \mathrm{L}$. Its highest concentration is in location $6(19.38 \mathrm{mg} / \mathrm{L})$. Its excess leads to build up in the gills which can produce deleterious effects in fish and other aquatic organisms. It may also inhibit the growth of plants by reducing photosynthentic activities

The mean value Cadmium $(\mathrm{Cd})$ is $0.03 \mathrm{mg} / \mathrm{L}$ which is above the FEPA limit of $0.01 \mathrm{mg} / \mathrm{L}$. Its accumulation in fish can cause a number of structural and pathomorphorlogical changes in various organ and its accumulation in aquatic mammals leads to increase hypertension, emphusema and kidney tubule damage.

The mean value of Zinc ( $\mathrm{Zn})$ is $5.82 \mathrm{mg} / \mathrm{L}$ which above the FEPA limit of $5.0 \mathrm{mg} / \mathrm{L}$. Excess of it causes nausea, vomiting, loss of appetite, abdominal cramps, and diarrhea. It highest concentration is in location 6 with $9.77 \mathrm{mg} / \mathrm{L}$. At acutely toxic concentrations it probably kills fish by destroying gill tissues. 
At chronically toxic levels it may induce stress resulting in death.

Nickel (Ni) is less than $0.01 \mathrm{mg} / \mathrm{L}$ across the study area which is less than the FEPA limit of $0.01 \mathrm{mg} / \mathrm{L}$. But when in excess it can inhibit the respiratory process and decrease ionic regulation which may lead to ionoregulation impairment, inhibition of respiration and promotion of oxidative stress in aquatic organisms.

The value of Lead $(\mathrm{Pb})$ is $0.50 \mathrm{mg} / \mathrm{L}$ which is higher than the FEPA limit of $0.05 \mathrm{mg} / \mathrm{L}$ with the highest concentration in location $4(0.88 \mathrm{mg} / \mathrm{L})$, its presence can be lethal affecting neurology and other developmental progression will be inhibited in aquatic organism. It also leads to oxidation stress in fish which induces synaptic damage and neurotransmitter malfunction in fish as neurotoxicity.

The mean value of Mercury $(\mathrm{Hg})$ is $0.31 \mathrm{mg} / \mathrm{L}$ which is higher than the FEPA limit of $0.001 \mathrm{mg} / \mathrm{L}$ with it highest concentration in location $4(2.9 \mathrm{mg} / \mathrm{L})$, its presence in excess may cause sublethal impacts in aquatic organisms such as delayed growth, reproductive impairment and greater incidence of diseases.

The mean value of Vanadium (V) is less than $0.01 \mathrm{mg} / \mathrm{L}$ across the various locations in the study and its negligible compared to the FEPA limit of $0.01 \mathrm{mg} / \mathrm{L}$. However, when present in excess it leads to sublethal toxicity and biochemical alterations in aquatic organisms.

\section{CONCLUSION}

The study shows that apart from $\mathrm{As}, \mathrm{Ba}, \mathrm{Ni}$ and $\mathrm{V}$ were below the FEPA limit. The range of concentration of metals that were above the FEPA limit are the in the order of $\mathrm{Cd}<\mathrm{Cu}<\mathrm{Ma}<\mathrm{Hg}<\mathrm{Pb}<\mathrm{Zn}<\mathrm{Cr}<<\mathrm{Fe}$. The presence of the metals above FEPA limit in the aquatic ecosystem is of great threat to aquatic plants and organisms.

\section{REFERENCES}

[1] S. Shrestha, F. Kazama. Assessment of surface water quality using multivariate statistical techniques: A case study of the Fuji river basin, Japan. Environmental Modelling and Software, 22: 2017, pp. 464-475.

[2] J. L. Zheng, Z. Luo, Q. L. Chen, X. Liu, C. X. Liu, Y. H. Zhao, , et al. Effect of waterborne zinc exposure on metal accumulation, enzymatic activities and histology of Synechogobius hasta. Ecotoxicol. Environ. Saf. 74, 2011, pp.1864-1873.

[3] M. P. Lanfranconi, R. Bosch, B. Nogales. 'Short-term Changes in the Composition of Active Marine Bacterial Assemblages in Response to Diesel Oil Pollution'. Microbial Biotechnology 2010; pp.3: 607-621.

[4] M. Lewis, R. Pryor. 'Toxcities of Oils, Dispersants and Dispersed Oils to Algae and Aquatic Plants: Review and Database Value to Resource Sustainability'. Environmental Pollution, 180: 2013, pp. 345-467.

[5] M. Teramoto, M. Ohuchi, A. Hatmanti, Y. Darmayati, Y.,Widyastuti, S. Harayama, \& Y. Fukunaga. 'Oleibacter Marinus gen. nov., sp. nov., a Bacterium that Degrades PetroleumAliphatic Hydrocarbons in a Tropical Marine Environment'. International Journal of Systematic Evolution and Microbiology; 61: 2011, pp. 375-380.

[6] [6] T. J. McGenity, B. D. Folwell, B. A. McKew, G.O. \&Sanni, 2012) 'Marine Crude-oil Biodegradation: A Central Role for Interspecies Interaction'. Aquatic Biosystems, 8(10): 2012, pp.1-19.
[7] J. Levy, C. Gopalakrishnan. 'Promoting Ecological Sustainability and Community Resilience in the US Gulf Coast After the Deep Ocean Horizon Oil Spill'. Journal of Natural Resource Pollution Research, 2: 2010, pp. 297-315.

[8] F. Liu, X. Wang, Y. Qian, S. Kong, M. Zheng. Emergency Rescue Decision Assistant System Based on GIS for Natural Gas Pipeline [C]. In Reston, VA: ASCE copyright Proceedings of the International Conference on Pipelines and Trenchless Technology 2011 October 26. 29, 2011, Beijing, china|d 20110000. American Society of Civil Engineers.

[9] P. M. Nyenje, J. W. Foppen, S. Uhlenbrook, R. Kulabako, A. Muwanga, Eu-trophication and nutrient release in urban areas of sub-Saharan Africa - A review. Sci-ence of Total Environment, 408: 2010, pp. 447-455.

[10] S. Dan'azumi, M. H. Bichi, Industrial Pollution and Heavy Metals Profile of Challawa River in Kano, Nigeria. Journal of Applied Sciences in Environmental Sanitation, 5 (6): 2010, pp. 56-62.

[11] E. Emmanuel, O. Odjadjare, I. O. Anthony, Physicochemical quality of an urban Municipal wastewater effluent and its impact on the receiving environment. Envi-ronmental Monitoring and Assessment, 170 (3): 2010, pp. 383-394.

[12] G. M. Dethloff, D. Schlenk, J. T. Hamm, H. C Bailey, "Alteration in physiological parameters of rainbow trout (Oncorhynchus mykiss) with exposure to copper and copper/zinc mixtures." Ecotoxicol. Environ. Saf. 42, 1999, pp. 253-264.

[13] I. Orun, Z. S. Talas, Antioxidative role of sodium selenite against the toxic effect of heavy metals $\left(\mathrm{Cd}^{2+}, \mathrm{Cr}^{3+}\right)$ on some biochemical and hematological parameters in the blood of rainbow trout (Oncorhynchus mykiss Walbaum, 1792). Fresenius Environ. Bull. 17, 2008, pp. 1242-1246.

[14] E. De Domenico, A. Mauceri, D. Giordano, M. Maisano, G. Gioffrè, A. Natalotto, et al. 2011). Effects of "in vivo" exposure to toxic sediments on juveniles of sea bass (Dicentrarchus labrax). Aquat. Toxicol. 105, 2011, pp. 688-697.

[15] C. Copat, M. V. Brundo, G. Arena, A. Grasso, G. Oliveri Conti, C. Ledda, et al. Seasonal variation of bioaccumulation in Engraulis encrasicolus (Linneaus, 1758) and related biomarkers of exposure. Ecotoxicol. Environ. Saf. 86, 2012, pp. 31-37.

[16] G. Guerriero, S. Trocchia, F. K. Abdel-Gawad, G. Ciarcia, 2014) Roles of reactive oxygen species in the spermatogenesis regulation. Front. Endocrinol. 5: 2014, pp. 56- 62.

[17] S. Fasulo, G. Guerriero, S. Cappello, M. Colasanti, T. Schettino, C. Leonzio, et al.. The "SYSTEMS BIOLOGY" in the study of xenobiotic effects on marine organisms for evaluation of the environmental health status: biotechnological applications for potential recovery strategies. Rev. Environ. Sci. Biotechnol. 14, 2015, pp. 339-345.

[18] F. Kpee, O. A. Ekpete, Levels of trace metals in surface sediments of Kalabari Creeks, Rivers Stae, Nigeria. Journal of Applied Science and Environmental Management, 81 (2): 2014, pp. 189-195.

[19] F. Coulon, P. M. Chronoupolou, A Fahy, S. Païssé, M. S. Goñi-Urriza, L. Peperzak, Acuña-Alvarez, B. A. McKew, C. Brussard, G. J. C. Underwood, K. N. Timmis, R. Duran, T. J. McGenity. 'Central Role of Dynamic Tidal Biofilms Dominated by Aerobic HydrocarbonoclasticBacteria and Diatoms in the Biodegradation of Hydrocarbons in Coastal Mudflats'. Applied and Environmental Microbiology, 78: 2012, pp. 3638-3648.

[20] C. P. Gerba, J. E. Smith, Sources of pathogenic microorganisms and their fate during land application of wastes. Journal of Environmental Quality, 34: 2005, pp. 42-48.

[21] W. A. Iyama, O. S. Edori. Comparative analysis of the water quality status of the Bassan rivers in Bayelsa State,Nigeria. International Journal of Chemistry and ChemicalEngineering, 6 (1): 2016, pp. 59-69. 